\title{
Maize Cannot Be Grown in Xiengkhouang Province?
}

\section{Xaysatith Souliyavongsa ${ }^{1}$, Nivong Sipaseuth ${ }^{1}$, Khonpany Dounphady ${ }^{1}$, Tasnee Attanandana ${ }^{2}$, Piboon Kanghae ${ }^{2}$, Russell Yost ${ }^{3}$, Sukunya Yampracha ${ }^{4}$, Sunan Kunaporn ${ }^{5}$}

\author{
${ }^{1}$ Department of Agriculture Land Management, Vientiane, Laos \\ ${ }^{2}$ Kasetsart University, Bangkok, Thailand \\ ${ }^{3}$ Department of Plant Production Technology, Faculty of Agricultural Technology, King Mongkut's Institute of Technology \\ Ladkrabang, Bangkok, Thailand \\ ${ }^{4}$ Department of Tropical Plant and Soil Science, University of Hawai'i, Honolulu, Hawaii \\ ${ }^{5}$ Land Development Department (Retired), Bangkok, Thailand \\ Email: *xay satith1@hotmail.com, rsyost@hawaii.edu
}

How to cite this paper: Souliyavongsa, X., Sipaseuth, N., Dounphady, K., Attanandana, T., Kanghae, P., Yost, R., Yampracha, S. and Kunaporn, S. (2019) Maize Cannot Be Grown in Xiengkhouang Province? Agricultural Sciences, 10, 1359-1369.

https://doi.org/10.4236/as.2019.1010099

Received: October 1, 2019

Accepted: October 22, 2019

Published: October 25, 2019

Copyright $\odot 2019$ by author(s) and Scientific Research Publishing Inc. This work is licensed under the Creative Commons Attribution International License (CC BY 4.0).

http://creativecommons.org/licenses/by/4.0/

\begin{abstract}
During a 2005 visit with National Agricultural and Forestry Institute (NAFRI) Director, Dr. Kouang Doungsila issued a challenge to these authors to determine if it was true that crops could not be grown in the extensive uplands of Xiengkhouang Province, Laos PDR. In response, a two-phase series of experiments was proposed and implemented. The Phase I experiment was to bring soil from the Xiengkhouang province uplands to a NAFRI greenhouse near Vientiane to assess possible nutrient requirements using a nutrient omission experiment. Simultaneously, soils were collected and analyzed from seven recognized agricultural regions of Laos. The initial Vientiane greenhouse experiment indicated that maize did grow, but there were multiple issues of extreme soil acidity and clear deficiencies of phosphorus and other nutrients. Phase II of the study included field studies on the site of soil selected for the greenhouse study. Field experiments were carried out for two years at the site with yields of maize exceeding $5500 \mathrm{~kg} \cdot \mathrm{ha}^{-1}$ in the first year and exceeding $6250 \mathrm{~kg} \cdot \mathrm{ha}^{-1}$ in a subsequent year. Intense symptoms of nutrient zinc (Zn) deficiency were observed, however. In 2008 another experiment was designed and carried out that included a $\mathrm{Zn}$ variable. The results from that experiment confirmed that maize yields nearing $6000 \mathrm{~kg} \cdot \mathrm{ha}^{-1}$ were indeed possible. Substantial amounts of lime were needed to correct the strong soil acidity, and a series of other nutrients including $\mathrm{N}, \mathrm{P}, \mathrm{K}$, and $\mathrm{Zn}$ were also required. Ongoing issues are where to obtain the extensive amounts of limestone needed as well as an evaluation of the residual effect of the limestone The finely ground, very reactive burnt lime residual effect was, as expected, short-lived. The re-
\end{abstract}


sults clearly demonstrated that, indeed, it was possible for maize to be produced in the extensive uplands of Xiengkhouang province, in answer to Director Khouang's challenging question.

\section{Keywords}

Lao Uplands, Food Security, Acid Soils of the Tropics

\section{Introduction}

According to the World Food Program's Comprehensive Food Security and Vulnerability Analysis of Laos, food insecurity is widespread throughout the country and alarmingly high in rural areas [1]. While Lao PDR has reduced the proportion of hungry poor to 23 percent, the 2015 Global Hunger Index still rates hunger levels as "serious". Climate change is expected to further worsen this situation [1]. The 2019 report further states that, $35.6 \%$ of children between 6 and 59 months suffer from chronic malnutrition and stunting [1]. One of the contributing factors is the insufficient production of food.

Local experience as of 2005 was that food crops such as maize could not be grown in the extensive highlands of the province of Xiengkhouang, Laos (Kouang Doungsila, 2005, personal communication). Director Doungsila personally challenged the authors of this study to examine that local opinion and conclusion and if true what solutions might be feasible. This manuscript describes the initial research studies carried out in response to Director Kouang's challenge. The study reports two phases. Phase 1 was a greenhouse investigation carried out by Konepany Dounphady [2] in controlled conditions in Vientiane. Phase 2, a field experiment was carried out by the senior author of this manuscript in Pek district, Xiengkhouang province in 2010. Both studies comprised Master's in Soil Science degrees at Kasetsart University, Bangkok, Thailand.

Other researchers in Laos have previously identified soil phosphorus $(\mathrm{P})$ as being among the nutrients that most limiting growth of rice in both uplands soils of Laos [3] [4] as well as in lowland soils [5]. A subsequent study also carried out by the senior author of this manuscript confirmed and quantified the extensive P deficiency in Lao uplands [6].

The plains of Xiengkhouang province of Laos are located in the northeast part of Laos and represent high potential for production of food and industrial crops such as maize. As of 2005 , only $5 \%$ of the plains were cultivated [7]. In the vicinity of the provincial capital of Xiengkhouang, it is estimated that more than 60,000 ha of acid, infertile savanna grassland was under-utilized by smallholders [8].

Limitations to food crop production by phosphorus are well-known in the tropics and a large number of technologies are available to diagnose and solve this pervasive problem [9]. 


\section{Objectives}

\section{Phase 1. Greenhouse}

- Was crop growth possible on soils of the uplands of Xiengkhouang Province, Lao PDR?

- What factors are most likely limiting crop growth on such upland soils?

Phase 2. Field

- Carry out confirmation studies in field conditions of the Lao uplands to confirm which nutrients or conditions were limiting crop growth in the extensive uplands of Xiengkhouang Province.

- Assess yield potential of maize in a site representative of upland soils and estimate amendments necessary to achieve maximum yield.

\section{Materials and Methods}

\section{Phase 1. Greenhouse studies}

Soils were collected, in 2006, from grasslands near Mee village, Pek district, Xiengkhouang Province Lao PDR (19²4'21.01"N; 1030.'38.48"E). Samples were taken from the $0-20 \mathrm{~cm}$ depth. Total $\mathrm{N}$ was determined by Kjeldahl analysis [10], available $P$ was extracted by Bray 2 [11], Mehlich 1 [12], and by the Fe-strip $\mathrm{Pi}$ [13] methods. Exchangeable $\mathrm{K}, \mathrm{Ca}, \mathrm{Mg}$, Na were extracted by $\mathrm{NH}_{4} \mathrm{OAc}, \mathrm{pH} 7$ [14], and cation exchange capacity (CEC) was measured by $\mathrm{NH}_{4} \mathrm{OAc}, \mathrm{pH} 7$ [14]. Organic matter (OM) was determined by the method of Walkley and Black [15]. Iron, $\mathrm{Mn}$, and $\mathrm{Zn}$ were extracted by the DTPA pH 7.3 method [16]. Extractable $\mathrm{Al}$ and $\mathrm{Fe}$ were measured by two methods-acid ammonium oxalate $\mathrm{pH} 3$ and the citrate bicarbonate dithionite method [17].

The taxonomic classification of the soils was determined using Soil Taxonomy [18].

Maize variety (Zea mays, L. "LVN10"), which was extensively grown in the Vientiane province was selected for the greenhouse study. The greenhouse study was conducted at the Dong Dok Station, Vientiane, during the late summer of 2006.

\section{Phase 2. Field studies}

A field experiment was begun in 2006 by Dounphady on the grasslands near Mee village, Pek district, Xiengkhouang Province [2]. The soil of this area was that used in the Phase 1 experiment at the Dong Dok Station, Vientiane. The soil was tentatively classified as a fine, kaolinitic, isohyperthermic, Typic Paleustult. Nutrient and chemical analysis is shown in Table 1 . This soil was very acid, high in $\mathrm{Al}$ and $\mathrm{Fe}$ oxides and also extremely P deficient. Lime, $3500 \mathrm{~kg} \cdot \mathrm{ha}^{-1}$ of $\mathrm{Ca}(\mathrm{OH})_{2}$, was applied two weeks prior to planting of the first crop (2006) and incorporated to a depth of $20 \mathrm{~cm}$ [2]. The field study of 2006 (data not shown) revealed that maize responded to $\mathrm{P}$ applications up to $56 \mathrm{~kg} \cdot \mathrm{P}_{2} \mathrm{O}_{5} \cdot \mathrm{ha}^{-1}$ but plants still appeared $\mathrm{P}$ deficient and zinc $(\mathrm{Zn})$ deficiency symptoms were also observed.

In 2007, an additional $300 \mathrm{~kg} \cdot \mathrm{ha}^{-1}$ of burnt limestone was added. 
Table 1. Characteristics of the Pek soil from the field experiment site, Xiengkhoung province, Laos. The sample was selected for the nutrient omission experiment.

\begin{tabular}{|c|c|}
\hline \multicolumn{2}{|c|}{ Pek } \\
\hline Texture & SCL \\
\hline Clay $\left(\mathrm{g} \cdot \mathrm{kg}^{-1}\right)^{1}$ & 323 \\
\hline Soil $\mathrm{pH}^{2}$ & 4.5 \\
\hline $\mathrm{OC}\left(\mathrm{g} \cdot \mathrm{kg}^{-1}\right)^{3}$ & 22.4 \\
\hline $\mathrm{CEC}\left(\mathrm{cmolc} \cdot \mathrm{kg}^{-1}\right)^{4}$ & 12.1 \\
\hline Total N(g. $\left.\mathrm{kg}^{-1}\right)^{5}$ & 1.00 \\
\hline Total P $\left(\mathrm{g} \cdot \mathrm{kg}^{-1}\right)^{6}$ & 2.40 \\
\hline $\mathrm{P}\left(\mathrm{mg} \cdot \mathrm{kg}^{-1}\right)^{7}$ & 1.46 \\
\hline $\mathrm{P}\left(\mathrm{mg} \cdot \mathrm{kg}^{-1}\right)^{8}$ & 0.85 \\
\hline $\mathrm{P}\left(\mathrm{mg} \cdot \mathrm{kg}^{-1}\right)^{9}$ & 0.60 \\
\hline $\mathrm{K}\left(\mathrm{cmolc} \cdot \mathrm{kg}^{-1}\right)^{10}$ & 0.12 \\
\hline $\mathrm{Ca}\left(\mathrm{cmolc} \cdot \mathrm{kg}^{-1}\right)^{10}$ & 0.56 \\
\hline $\mathrm{Mg}\left(\mathrm{cmolc} \cdot \mathrm{kg}^{-1}\right)^{10}$ & 0.09 \\
\hline $\mathrm{Na}\left(\mathrm{cmolc} \cdot \mathrm{kg}^{-1}\right)^{10}$ & 0.33 \\
\hline Feo $\left(g \cdot \mathrm{kg}^{-1}\right)^{11}$ & 3.91 \\
\hline Fed $\left(\mathrm{g} \cdot \mathrm{kg}^{-1}\right)^{12}$ & 21.8 \\
\hline Alo $\left(\mathrm{g} \cdot \mathrm{kg}^{-1}\right)^{11}$ & 3.07 \\
\hline Ald $\left(\mathrm{g} \cdot \mathrm{kg}^{-1}\right)^{12}$ & 7.65 \\
\hline
\end{tabular}

${ }^{1}$ Pipette method [23]; ${ }^{2}$ Glass electrode, 1:1 soil:water ratio; ${ }^{3}$ Walkley Black titration [15]; ${ }^{4} \mathrm{NH} 4 \mathrm{OAc}$, pH 7 replacement method [16]; ${ }^{5}$ Macro Kjeldhal methods [24]; ${ }^{6} \mathrm{Conc}$. $\mathrm{HNO}_{3}-\mathrm{H}_{2} \mathrm{SO}_{4}-\mathrm{HClO}_{4}$, ratio 5:1:2 [14]; ${ }^{7}$ Bray 2 method [11]; ${ }^{8}$ Mehlich-1 extractable P [12]; ${ }^{9}$ Pi-test [13]; ${ }^{10} \mathrm{NH} 4 \mathrm{OAc}$ pH 7 [25]; ${ }^{11}$ Ammonium oxalate $\mathrm{pH} 3$ in darkness [17]; ${ }^{12} \mathrm{Citrate}$ bicarbonate dithionite method [17].

Prior to planting the 2008 crop, the experimental plot was tilled as in years 2006 and 2007, N and K were applied at the same rate as previously by Dounphady, specifically $110 \mathrm{~kg} \cdot \mathrm{N} \cdot \mathrm{ha}^{-1}$ was applied as urea, $82 \mathrm{~kg} \cdot \mathrm{K} \cdot \mathrm{ha}^{-1}$ was applied as muriate of potash [2]. The $\mathrm{N}$ was split-applied two times, at 10 days as a basal dressing and at 30 days after planting as a top dressing. Phosphorus was applied as triple super phosphate as previously. In 2006 and 2007 the $\mathrm{P}$ application was $0,7,14,28$, and $56 \mathrm{~kg} \mathrm{P}_{2} \mathrm{O}_{5} \mathrm{ha}^{-1}$, incorporated. In 2008, $\mathrm{P}$ was re-applied in the same plot as $0,16,32,64$, and $128 \mathrm{~kg} \mathrm{P}_{2} \mathrm{O}_{5} \mathrm{ha}^{-1}$. The same variety of maize (Zea mays, L. "LVN10") was planted as in 2006 and 2007. This variety is adapted to growing conditions in other zones of the Lao PDR. A soil sample was composited from cores taken between the rows in each plot including 20 samples in 20 $\mathrm{cm}$ depth, and $\mathrm{P}$ was extracted by Bray 2, Mehlich 1 and the Fe-strip Pi.

The 2008 field experiment was laid out using an RCB design. The main plot size was $6 \mathrm{~m}$ long $\times 5 \mathrm{~m}$ wide with 8 rows and 200 plants. The plant spacing was $25 \mathrm{~cm}$ within the row $\times 75 \mathrm{~cm}$ between rows. Each main plot was divided into 
two subplots comprised of 4 rows. Each subplot either received or did not receive seed-applied $\mathrm{Zn}$ as a factor stripped over the entire experiment. Zinc sulfate $\left(4.78 \mathrm{~kg} \cdot \mathrm{Zn} \cdot \mathrm{ha}^{-1}\right.$ as $\left.\mathrm{ZnSO}_{4} \cdot 7 \mathrm{H}_{2} \mathrm{O}\right)$ was applied as a coating of the maize seed using a gum arabic solution as the adhesive. The solution was prepared by dissolving $75 \mathrm{~g}$ of gum arabic in $250 \mathrm{ml}$ boiling, deionized water. After cooling, the $\mathrm{ZnSO}_{4} \cdot 7 \mathrm{H}_{2} \mathrm{O}$ was added to the gum arabic solution and $937.5 \mathrm{~g}$ of maize seed (30 $\mathrm{kg} \cdot \mathrm{ha}^{-1}$ ) was put into the solution and mixed thoroughly [19].

\subsection{Grain and Stover Yield Collection}

Grain and Stover data were collected from the middle two rows in subplots of $\mathrm{Zn}$ and without $\mathrm{Zn}$ applied treatments. The two rows of plants and two plants of the beginning and the end of row were used as guard plants. The harvest area of grain and stover was $6 \mathrm{~m}^{2}$.

\subsection{Statistical Analysis}

Grain yields as affected by levels of $\mathrm{P}$ and $\mathrm{Zn}$ were analyzed using a strip-plot analysis with SAS [20] since the $\mathrm{Zn}$ was applied as a stripped factor. Yields of grain in 2008 were plotted versus $P$ applied in 2008 to assess whether maximum response to added $\mathrm{P}$ had been obtained.

Grain yields for 2008 versus $\mathrm{P}$ additions in 2008 were also analyzed using a linear-plateau model [21], which is an implementation of the linear response model presented by Anderson and Nelson [22].

\section{Results}

Phase 1. Soil Analysis and exploratory Greenhouse evaluation of nutrient limitations using a nutrient omission experiment at the Dong Dok experiment station, Vientiane.

Phase 2. Field study at Pek District, 2008 yields harvested (included $\mathrm{Zn}$ ).

\section{Discussion}

Phase 1. Results from both the soil analyses (Table 1) and the nutrient omission experiment (Table 2 and Figure 1), indicate that both soil $\mathrm{pH}$ and nutrient levels were extremely low and clearly were growth limiting for most food crops. The nutrient omission experiment clearly demonstrated that among nutrient limitations, the $\mathrm{P}$ deficiency limitation was one of the most growth limiting. At the same time, the experiment clearly demonstrated that maize could grow well if the soil constraints were alleviated in the soil from Xiengkhouang province and that there was a possibility of excellent maize growth in the extensive, un-cropped plains. These two results indicated that while extremely nutrient poor and extremely acidic, there was no other apparent reason for crops could not grow well in the extensive uplands of the province. 
Table 2. Response of maize in the Dong Dok greenhouse nutrient omission experiment. Measurements taken 55 days after planting (see also Figure 1).

\begin{tabular}{cc}
\hline Fertilizer rates: $\left(\mathrm{N}-\mathrm{P}_{2} \mathrm{O}_{5}-\mathrm{K}_{2} \mathrm{O}-\mathrm{ZnSO}_{4}\right)$ & Dry weight $(\mathrm{g} /$ pot $)$ \\
\hline Lime applied $(8.70 \mathrm{~g} /$ pot $)$ & \\
\hline $\mathrm{T} 1: 0-0-0-0$ & $29.3 \mathrm{c}^{1}$ \\
$\mathrm{~T} 2:-\mathrm{N}$ & $73.3 \mathrm{~b}$ \\
$\mathrm{~T} 3:-\mathrm{P}$ & $28.2 \mathrm{c}$ \\
$\mathrm{T} 4:-\mathrm{K}$ & $75.9 \mathrm{ab}$ \\
$\mathrm{T} 5:-\mathrm{Zn}$ & $88.9 \mathrm{ab}$ \\
$\mathrm{T} 6:+\mathrm{N},+\mathrm{P},+\mathrm{K},+\mathrm{Zn}$ & $96.2 \mathrm{a}$ \\
\hline
\end{tabular}

${ }^{1}$ Dry weights with the same letter did not differ at the $\mathrm{P}=0.01$.

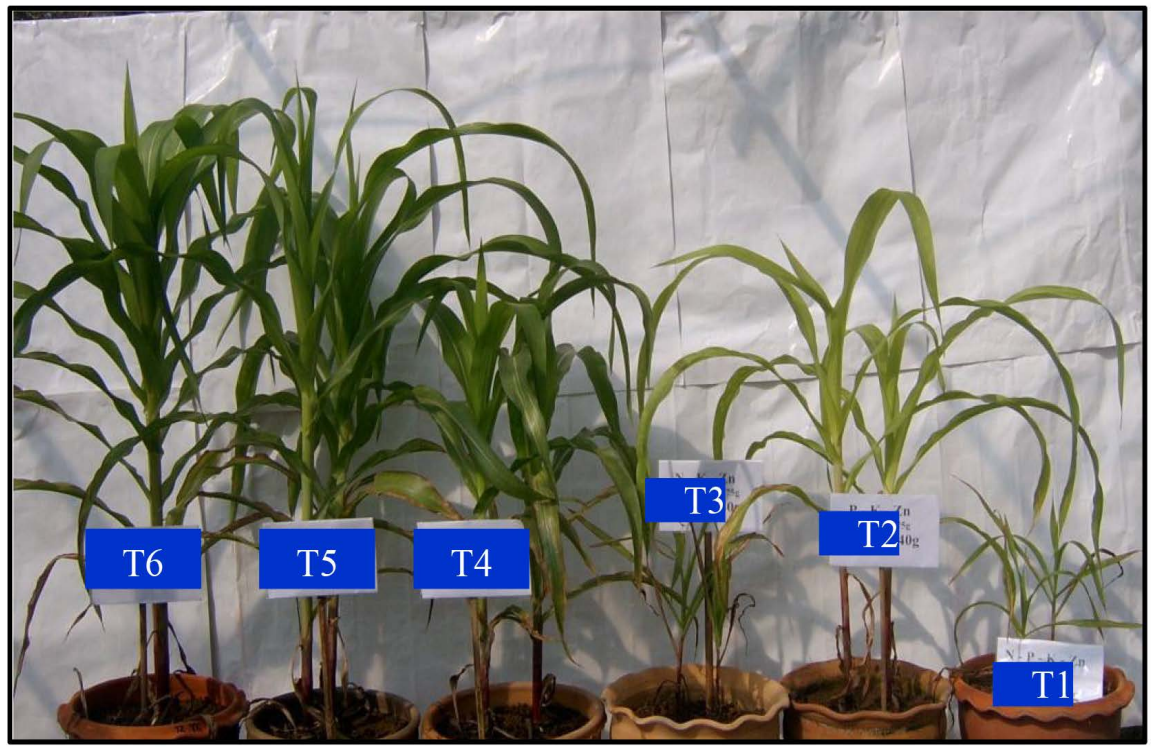

Figure 1. Maize growth at 55 days after planting in the nutrient omission experiment, Dong Dok Station, Vientiane.

Phase 2. The second phase of the response to the challenge delivered by Director Doungsila was to carry out field experiments in Xiengkhouang province. This was begun by student Konepany Dounphady in 2006 and 2007 and demonstrated that soil of the Pek district could support a complete growth cycle of maize. Two initial crops of maize carried out in 2006 and 2007 indicating that initial estimates of required levels of $\mathrm{P}$ were too low. This was confirmed in a country-wide survey of the seven major agricultural provinces of Laos: Champasak, Luang Prabang, Salavanh, Sekong, Vientiane, Xayaboury, and Xiengkhuang [6]. During the 2006 and 2007 maize experiments, a severe Zn deficiency was observed and thus the 2008 experiment included a strip plot application of $\mathrm{Zn}$.

The results of the 2008 experiment confirmed that maize could be grown very successfully on the upland soils of Pek district and likely in other districts of the 
extensive Xiengkhouang uplands (Table 3). Of particular interest was the result that yields increased with the additional application of P (Figure 2). The application of $\mathrm{Zn}$ confirming earlier observations that it might be limiting. It was also interesting that the response to the addition of $\mathrm{Zn}$ was even greater at high levels of applied P. Maize response as measured by stover yields also increased markedly as well.

A soil analysis taken subsequent to the 2008 harvest pointed out several additional issues with growing crops on such acid soils (Table 4). The limestone initially added was burnt limestone, $\mathrm{CaO}$, and as such it was extremely fine powder, which neutralized the soil acidity very rapidly, but does not typically have a long residual effectiveness. A slight decrease in soil $\mathrm{pH}$ was observed after the 2006 crop and some $300 \mathrm{~kg}$ was additionally applied prior to the $2007 \mathrm{crop}$. Soil $\mathrm{pH}$ after the 2008 crop was again in the very low ranging of 4.5 to 4.7. This soil $\mathrm{pH}$ is again too low and suggests additional liming is surely needed. This result is not surprising, because the initially applied burnt lime is ideal for quick acting, but does not have a long residual effectiveness. Consequently, it seems imperative that alternative sources of agricultural limestone are needed and a strong suggestion is to explore local reserves of naturally occurring limestone for a low-cost, locally available material. The use of the expensive burnt limestone, likely is financially profitable only for the extremely high value crops. If other soils are similarly deficient in $\mathrm{Zn}$, then the provision of $\mathrm{Zn}$ as part of a foundation fertilization may be warranted.

Table 3. Grain and stover yield, Pek District, Xiengkhouang, Laos in 2008.

\begin{tabular}{|c|c|c|c|c|}
\hline \multirow{2}{*}{$\begin{array}{c}\text { P rates } \\
\left(\mathrm{kg} \cdot \mathrm{ha}^{-1} \cdot \mathrm{P}_{2} \mathrm{O}_{5}\right)\end{array}$} & \multicolumn{2}{|c|}{$\begin{array}{c}\text { Grain yield } \\
\left(\mathrm{kg} \cdot \mathrm{ha}^{-1}\right)\end{array}$} & \multicolumn{2}{|c|}{$\begin{array}{c}\text { Stover yield } \\
\left(\mathrm{kg} \cdot \mathrm{ha}^{-1}\right)\end{array}$} \\
\hline & $\mathrm{Zn}$ & No Zn & $\mathrm{Zn}$ & No Zn \\
\hline 0 & 1382 & 1302 & 2593 & 1893 \\
\hline 16 & 3382 & 2945 & 5276 & 5078 \\
\hline 32 & 4169 & 3246 & 6732 & 6189 \\
\hline 64 & 4991 & 4213 & 10,462 & 9577 \\
\hline 128 & 5735 & 4418 & 12,197 & 11,063 \\
\hline Zn applied & \multicolumn{2}{|c|}{ ** } & \multicolumn{2}{|c|}{ * } \\
\hline $\mathrm{P}$ applied & \multicolumn{2}{|c|}{$* *$} & \multicolumn{2}{|c|}{$* *$} \\
\hline Zn applied ${ }^{\star} \mathrm{P}$ applied & \multicolumn{2}{|c|}{ NS } & \multicolumn{2}{|c|}{ NS } \\
\hline CV\% & \multicolumn{2}{|c|}{15.26} & \multicolumn{2}{|c|}{14.31} \\
\hline F-test & 67.02 & 17.78 & 94.67 & 100.81 \\
\hline Intercept & 1584.80 & 1302.01 & 2921.00 & 2489.90 \\
\hline Slope & 199.1 & 234.74 & 273.1 & 260.8 \\
\hline Node & 18.98 & 11.33 & 33.97 & 32.87 \\
\hline
\end{tabular}

Note $^{*}=$ Significantly different at $95 \%$; ${ }^{* *}=$ Significantly different at $99 \%$; NS $=$ Not significant. 
Table 4. Soil chemical analysis after harvest in 2008.

\begin{tabular}{ccccccc}
\hline $\mathrm{P}$ rates & $\mathrm{ZnSO}_{4} \cdot 7 \mathrm{H}_{2} \mathrm{O}$ & $\mathrm{pH}$ & $\mathrm{Zn}(\mathrm{DTPA})$ & $\mathrm{P}_{\text {Bray } 2}$ & $\mathrm{P}_{\text {Mehlich1 }}$ & $\mathrm{P}_{\text {Fe-strip Pi }}$ \\
\hline$\left(\mathrm{kg} \cdot \mathrm{P}_{2} \mathrm{O}_{5} \cdot \mathrm{ha}^{-1}\right)$ & $\left(\mathrm{kg} \cdot \mathrm{ha}^{-1}\right)$ & $(1: 1)$ & $\left(\mathrm{mg} \cdot \mathrm{kg}^{-1}\right)$ & $------------\left(\mathrm{mg} \cdot \mathrm{kg}^{-1}\right)-----------$ \\
\hline 0 & 4.72 & 4.5 & 0.52 & 3.12 & 2.86 & 1.33 \\
16 & 4.72 & 4.7 & 0.63 & 5.44 & 3.85 & 1.89 \\
32 & 4.72 & 4.6 & 0.36 & 12.88 & 8.24 & 5.55 \\
64 & 4.72 & 4.6 & 0.20 & 25.32 & 21.05 & 16.24 \\
128 & 4.72 & 4.7 & 0.64 & 32.25 & 28.20 & 22.45 \\
0 & 0 & 4.6 & 0.23 & 3.34 & 3.19 & 1.45 \\
16 & 0 & 4.9 & 0.21 & 5.94 & 3.96 & 2.04 \\
32 & 0 & 4.4 & 0.23 & 13.45 & 4.81 & 5.34 \\
64 & 0 & 4.8 & 0.38 & 29.23 & 15.24 & 13.55 \\
128 & 0 & 4.8 & 0.17 & 37.52 & 32.00 & 22.86 \\
\hline
\end{tabular}

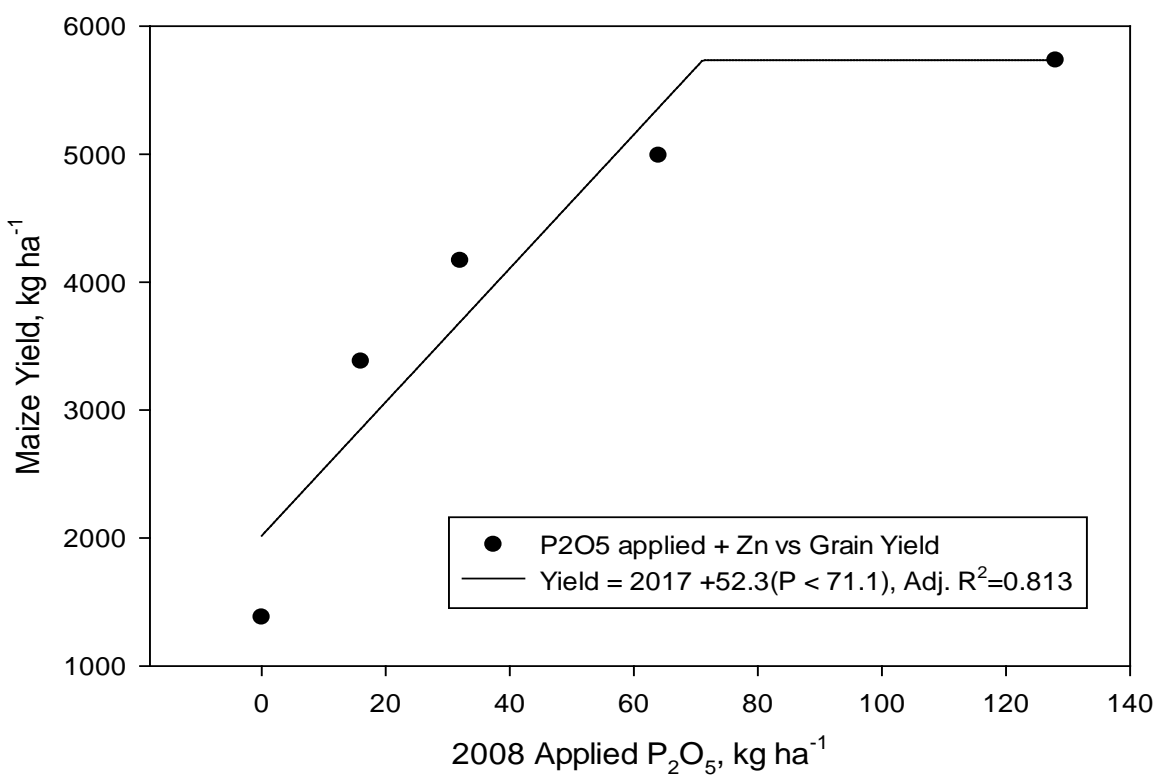

Figure 2. Maize grain yield 2008. Phosphate applied in 2008.

These results clearly provide a strong affirmative answer to Director Doungsila's challenge question as to what does it take to grow crops in the extensive Xiengkhoung uplands. We profoundly thank Director Khouang for his valuable, foresighted challenge.

\section{Conclusions and Recommendations}

The utility of classifying the soils can be illustrated by pointing out that the soil at the site of the experiment; Pek, was classified as a Typic Paleustult, indicating a highly weathered, acid, low nutrient capacity soil as well as low nutrient containing. The results show that these soils were both infertile and acid and will 
require substantial lime and fertilizer inputs, but can become highly productive if properly managed. Similar soils are highly productive elsewhere in the tropics.

It was observed that the soils had become acid again ( $\mathrm{pH} 4.6)$ suggesting that the quick-acting burnt lime had a residual effect of approximately 2 to 3 years.

The expected productivity of LVN10 variety of maize was about $6-7 \mathrm{t} \cdot \mathrm{ha}^{-1}$. The field experiment results suggested that the $\mathrm{P}$ requirement of this area was 71 $\mathrm{kg} \cdot \mathrm{P}_{2} \mathrm{O}_{5} \cdot \mathrm{ha}^{-1}$. Besides the lime and $\mathrm{P}$ applications, it was shown that $\mathrm{Zn}$ was necessary for maize production in Xiengkhouang province.

The results of this study indicate that high yields of food crops were possible with proper management. The soil $\mathrm{pH}$ should be increased to be $5.5-6$ with local liming materials and adequate amounts of $\mathrm{P}$ and $\mathrm{Zn}$ fertilizer applied. Moreover, planting with native legumes or other acid tolerant plants during the dry season and the incorporation of the residues into the soil is also recommended, especially when maize is to be grown. Gradually, the soil will be improved to better physical and chemical properties. These results suggest that the region has enormous potential to support food crops and to improve food security of the region.

\section{Conflicts of Interest}

The authors declare no conflicts of interest regarding the publication of this paper.

\section{References}

[1] World Food Programme (2019) Lao People's Democratic Republic. https://www.wfp.org/countries/lao-peoples-democratic-republic

[2] Dounphady, K. (2009) Estimating Phosphorus Fertilizer Application Rates for Maize in Selected Soils of Laos. Kasetsart University, Bangkok, Thailand.

[3] Vonghachack, S. (2000) Soil and Soil Fertility in Laos. Soil Survey and Land Classification Center, Vientiane, Laos.

[4] Linquist, B. and Pheng, S. (2001) Nutrient Management in Rainfed Lowland Rice in the Lao PDR. International Rice Research Institute, Los Banos, Philippines, 88 p.

[5] Linquist, B., Kazuki, S., Keoboualapha, B., Phengchan, S. and Phanthaboon, K. (2006) Improving Upland Rice-Based Cropping Systems in Laos. In: Schiller, J.M., Chanphengxay, M.B., Linquist, B. and Appa Rao, S., Eds., Rice in Laos, International Rice Research Institute, Los Banos.

[6] Xaysathid, S., Yampracha, S., Attanandana, T., Yost, R. and Kanghae, P. (2015) Phosphorus-Sorption Characteristics and Phosphorus Buffer Coefficients of Some Important Soils in Lao PDR. Communications in Soil Science and Plant Analysis, 46, 666-681. https://doi.org/10.1080/00103624.2015.1005225

[7] Lienhard, P., Sosomphou, T., Siphongxay, S., Tivet, F. and Seguy, L. (2005) Improving Feed Resources for Animals in Small Holder Farming Systems, Xiengkhouang Province, Lao PDR. In: Tivet, F., Tran Quoc, H., Lienhard, P., Chabanne, A. and Panyasiri, K., Eds., Development and Implementation of Direct Seeding Mulch Based Cropping Systems in South-East Asia, Lao National AgroEcology Programme-PRONAE, PCADR. 
[8] Tivet, F., Tran Quoc, H., Lienhard, P., Chabanne, A. and Panyasiri, K. (2005) Development and Implementation of Direct Seeding Mulch Based Cropping Systems in South-East Asia. Lao National Agro-Ecology Programme-PRONAE, PCADR.

[9] Sanchez, P.A. (2019) Properties and Management of Soils of the Tropics. 2nd Edition, Cambridge University Press, Cambridge, United Kingdom.

[10] Kjeldahl, J.A. (1883) New Method for the Determination of Nitrogen in Organic Matter. Zeitschreft fur Analytische Chemie. In: Holcombe, E.E., Moore, D.G. and Fredriksen, R.L., Eds., An Improved Method of Chemical Analysis for Low Levels of Nitrogen in Forest Stream or in Rain Water, USDA. Forest Service.

[11] Bray, R.H. and Kurtz, L.T. (1945) Determination of Total, Organic, and Available Forms of Phosphorus in Soils. Soil Science, 59, 39-45. https://doi.org/10.1097/00010694-194501000-00006

[12] Mehlich, A. (1953) Determination of $\mathrm{P}, \mathrm{Ca}, \mathrm{Mg}, \mathrm{K}, \mathrm{Na}$ and $\mathrm{NH}_{4}$. North Carolina Soil Test Division Mimeo.

[13] Chardon, W.J., Menon, R.G. and Chien, S.H. (1996) Iron Oxide Impregnated Filter Paper (Pi Test): A Review of Its Development and Methodological Research. $\mathrm{Nu}^{-}$ trient Cycling in Agroecosystems, 46, 41-51. https://doi.org/10.1007/BF00210223

[14] Yoshida, S., Forno, D.A. and Cook, J.H. (1972) Laboratory Manual for Physiological Studies of Rice. The International Rice Research Institute, Philippines.

[15] Walkley, A. and Black, C.A. (1934) An Examination of the Degtjareff Method for Determining Soil Organic Matter and a Proposed Modification of the Chromic Titration Method. Soil Science, 37, 29-38. https://doi.org/10.1097/00010694-193401000-00003

[16] Lindsay, W.L. and Norwell, W.A. (1978) Development of DTPA Soil Test for Zinc, Iron, Manganese and Copper. Science Society of America Journal, 42, 421-428. https://doi.org/10.2136/sssaj1978.03615995004200030009x

[17] Loeppert, R.H. and Inskeep, W.P. (1996) Iron. In: Sparks, D.L., Ed., Methods of Soil Analysis: Part 3, Chemical Methods, Soil Science Society of America Inc. and American Society of Agronomy Inc., Madison, WI, 639-663.

[18] Soil Survey Staff (1999) Soil Taxonomy: A Basic System of Soil Classification for Making and Interpreting Soil Surveys. Agricultural Handbook No. 436. USDA Natural Resources Conservation Service, Washington DC, 869.

[19] Rattanarat, S., Pongsakul, P., Rattananukul, S., Marsangsan, V. and Arayangkul, T. (1983) Application of $\mathrm{Zn}, \mathrm{Mo}$ and Ground Limestone for Field Crops by Seed Coating. Proceeding of the 21st Annual Conference Plant Science, Kasetsart University.

[20] SAS, Inc. (2017) Statistical Analysis System, Cary, NC, USA.

[21] Shuai, X., Zhou, Z. and Yost, R.S. (2003) Using Segmented Regression Models to Fit Soil Nutrient and Soybean Grain Yield Changes Due to Liming. Journal of Agricultural, Biological, and Environmental Statistics, 8, 240-252.

https://doi.org/10.1198/108571103322161586

[22] Anderson, R.L. and Nelson, L.A. (1975) A Family of Models Involving Intersecting Straight Lines and Concomitant Experimental Designs Useful in Evaluating Response to Fertilizer Nutrients. Biometrics, 31, 303-318. https://doi.org/10.2307/2529422

[23] Day, P.R. (1965) Particle Fraction and Particle Size Analysis. In: Black, C.A., Ed., Method of Soil Analysis. Part 1. Agron, Madison, WI, 545-567.

[24] Bremner, J.M. (1996) Nitrogen-Total. In: Sparks, D.L., Page, A.L., Helmke, P.A, 
Loeppert, R.H., Soltanpour, P.N., Tabatabai, M.A., Johnston, C.T. and Sumner, M.E., Eds., Methods of Soil Analysis, Part 3 Chemical Methods, Soil Science Society of America, Madison, WI, 1085-1121.

[25] Jones, J.B. (2001) Laboratory Guide for Conducting Soil Tests and Plant Analysis. CRC Press, Boca Raton, FL. https://doi.org/10.1201/9781420025293 